THURSDAY, MAY 17,1883

\section{THE FISHERIES EXHIBITION}

"Do you know me, my lord?

Excellent well ; you are a fishmonger."-Hamlet.

$7 \mathrm{HE}$ exhibition which was opened last Saturday by the Prince of Wales on behalf of Her Majesty the Queen is the latest of a series of such shows of matters relating to fish and fishing apparatus which was initiated by the French at Arcachon, other exhibitions having followed in subsequent years at Amsterdam, at Norwich, at Berlin, and at Edinburgh. Though in this country the accumulated knowledge and experience of scientific zoologists is not made use of either by the Government, or by local authorities, or by private capitalists in order to render our fisheries more productive, or to prevent the total destruction of some branches of them (except in the case of the salmon fisheries), yet the Fisheries Exhibition will have some interest for scientific men and for the readers of NATURE.

It is true that the present exhibition differs from its continental predecessors in the fact that it is a private undertaking entirely organised by practical men who would disclaim the title of "scientific" for themselves, and who have not largely availed themselves of the services of the professional zoologists of the country in carrying out their enterprise. Nevertheless the exhibition will have a scientific character and importance in consequence of the fact that almost without exception every foreign country which takes part in the exhibition is represented by distinguished zoologists, who have been delegated by the governments of the countries to which they belong, to take charge of and to organise the exhibition of such objects as in their judgment may best serve to illustrate the vast variety of matters of interest and instruction connected with their fisheries. From the republican United States of America, from democratic Norway, from Holland, from Sweden, and from Italy skilled zoologists have been sent by their respective Governments and are at this moment in London in order both to teach and to learn at the fisheries show.

It will be interesting to compare the results which these skilled officials and men of science can produce with those offered by the crowd of independent English exhibitors, manufacturers, fishery owners, fishmongers, and naturalists. Hitherto in the great fishery exhibitions England has been represented at a great disadvantage, for although the Governmental departments of fisheries control and inspection of foreign states have cordially responded to the invitation sent by the committee of the present London exhibition, yet on no occasion has the English Government assisted to place before the public in other countries any of the methods or products of English fishing. On the present occasion, though as hitherto the Englisb Government has no official machinery for representing or dealing with British fisheries generally, and pracically takes no part in the affair, yet in consequence of the activity of the large committee of gentlemen who have organised the exhibition, we shall no doubt see a much fuller representation of British fishing enterprise than at any former exhibition.

VoL. Xxvirr.-No. 707
It is too soon at this moment, when many cases of objects are still unopened and sufficient time for a careful inspection of the exhibits has not elapsed, to offer any detailed remarks on the teaching to be derived from the fisheries show. On Saturday the special exhibit, which cannot be retained permanently during the whole period for which the show is open, was that of the fisherfolk themselves. Amongst the men the East Anglian herring fishers of Yarmouth and Lowestoft carried off the palm by their fine physique, intelligent faces, and sturdy bearing, wonderfully like to their brother Norsemen from the other side of the North Sea. These and the bright fearless faces of the Newhaven fisher-girls as they sat side by side with the strangely capped women from Boulogne and from the Dutch and Belgian coast, who good naturedly took part in the ceremony of Saturday last, were sufficient to demonstrate that whether British fisheries need or do not need to be improved and developed by that scientific supervision which is applied to the harvest of the sea on foreign shores, the race of men and women occupied in carrying on those fisheries bring to their business the fullest measure of intelligence and physical capacity. It is due to the courage, skill, and vigour of these fisherfolk that British fisheries continue to flourish, though their enterprise is unaided by the science of a Government department and their market is systematically injured by the devices of "middle-men."

Possibly the London Fisheries Exhibition of I883 may have a result in regard to the British interests there represented similar to that which the Great Exhibition of $185 \mathrm{r}$ effected in regard to the various art manufactures of the country. Just as the public demonstration of British inferiority in the matter of artistic workmanship led to the action of the Government in promoting a remedy in the foundation of schools of art and design, so the extraordinary contrast afforded by the British and Foreign exhibits on the present occasion in all that relates to a reasonable use of accurate knowledge (otherwise called science) in dealing with fish, oysters, Iobsters, \&c., may lead to an effort on the part of the constituted authority to imitate in some way the action of foreign governments (whether popular or paternal) in retaining the services of competent zoologists for the purpose of continually acquiring new knowledge in regard to fishes, and in particular of devising new ways of increasing and protecting the annual yield of fishes in the market.

It is a remarkable fact that for the purpose of dealing with questions and effecting practical objects connected with the economic aspects of the vegetable kingdom, the British Government supports the most efficiently organised botanical institution in the world. The Royal Gardens at Kew are the source of a ceaseless stream of scientific information and advice which is poured by every mail into all parts of the globe where our colonies extend, and it may be truly said that the pecuniary value of the scientific knowledge to British commercial enterprise, which has thus been furnished, is gigantic.

It does not admit of any question, that a parallel, though not in the first instance so vast a service, might be rendered to British industrial and commercial interests by a governmental zoulogical institution, to the scientific staff of which might be intrusted for study and control, not only matters relating to the sea- and river-fisberies of these 
islands, our oyster, lobster, and shell-fish fisheries, but also matters concerning the pearl fisheries of India, the spongefisheries of the Bahamas, and the possible coral fisheries of the Australian coast. Further, the duties which even among the self-helping inhabitants of the United States are assigned to a State entomologist, might here also be discharged. From the duly established officials of such a state zoological laboratory or institute, the Foreign Office and the Colonial Office could at once obtain full and decisive information enabling them to act intelligently in relation to the importation of the Phylloxera pest, whilst the Home Office might gain courage in the presence of the Colorado beetle. It seems strange that the creation of an official laboratory of economic zoology has been so long delayed.

We shall be able to judge in the case of the present exhibition whether the cooperation of scientific men would have rendered the English department more instructive than it is under the present conditions, as compared with the scientifically organised exhibits of foreign countries. The comparison of the official catalogue of the London Exhibition with that of the Berlin Exhibition will be important in the same direction. With regard to the essays for which the committee has offered prizes, it may at once be stated that unfortunately no steps have been taken to bring the questions concerning which treatises are desired under the notice of the persons most likely to be able to deal with them satisfactorily either in this country or abroad. A series of valuable reports might have been obtained and circulated in connection with the exhibition by a sufficiently public appeal to the zoological world made in due time. It may yet be not too late to take some steps in this matter.

\section{SCIENCE AND ART}

$\mathrm{NO}$ one will be surprised that $\mathrm{Mr}$. Huxley took 1 advantage of the opportunity afforded him at the Academy dinner to reply to some remarks made by Mr. Matthew Arnold on a like occasion two years ago. Mr. Arnold, we presume, does not claim to possess that amount of knowledge either of art or of science which would render him a prejudiced witness, and, being unprejudiced, he drew a terrible picture of the future of art, not only in this, but in all other countries, unless some very decided steps were taken. Time out of mind, according to $\mathrm{Mr}$. Arnold, art and literature had divided the sweets and beauties of this world between them, but now, in these latter days, that terrible thing science-.

" Monstrum horrendum, informe, ingens, cui lumen ademptum," was about to bar their future progress, and invade and destroy the fair kingdoms of thought and work gained from the unknown by the labours of both. Hence the necessity of an alliance offensive and defensive against the common enemy; hence the artist and the man of letters were to band themselves together to stamp this new hydra from out the land.

It was not to be expected that such a view as this would be allowed to pass unchallenged by $\mathrm{Mr}$. Huxley. He declined to regard science as an invading and aggressive power, eager to banish all other pursuits from the universe. Putting Mr. Matthew Arnold's view in a more concrete form, he represented it as picturing. science rising as a monster from out the troubled waters of the sea of modern thought, intent upon devouring the unprotected Andromeda of Art. For him Literature was Perseus equipped with the swift shoes of the ready writer, and the cap of invisibility of the editorial article, wbile the death-dealing quality of Medusa's head had a fitting representative in the sting of vituperation. Mr. Huxley's remarks dealt less with Andromeda than with Perseus, to whom he suggested the advisability of thinking twice before trying conclusions with the risen monster. He ended by showing how necessary Art and Science were to each other, how each was strong in the other's strength, and how they were never likely to be sundered, but were certain to twine round each other more closely; and to help each other more as time went on. Agreeing as we do altogether with Mr. Huxley, we think, however, that another view is worthy of consideration. For ourselves, although likening art to fair and chained Andromeda, we cannot admit that science is correctly represented in the form of the monster. Without further considering of whom or of what the monster may be typical, it seems to us perfectly certain that the Perseus of whom the Andromeda of Art stands so much in need is not Literature, but Science, because this Perseus alone can give the help and render the assistance which the maiden needs so sorely at the present moment.

Occasion has been before taken in these columns to point out how one of the greatest revivals of art in the history of the world was contemporaneous with the dawn of one of those sciences which must for ever lie at the base of much work in art: we refer to the science of anatomy; and when one looks round this year's Academy and compares the work based upon this branch of knowledge, the anatomy of form, with that connected with the other branch of knowledge which has to do with the anatomy of light and colour, one cannot but feel that the Andromeda of Art is being sacrificed indeed. Land scape painting has as close a connection with physical science as figure painting has with anatomy, and we cannot help thinking it is because physical science has not been sufficiently taught in our public schools, that our landscape painting is, if we are to judge by this year's pictures, not advancing, but almost retrograding. The man who finds anatomy too difficult for him and rushes into landscape soon discovers that there is something there which he has not learned, but which has to be learned ere he can achieve distinction; and like too many others he has to give up the battle ingloriously. Not for many years has there been such an absence of landscapes of the highest order as in the present Academy; and in order to show, on the one hand, how those artists who have some knowledge of the branches of science which bear upon their work in art have succeeded in filling their canvases with worthy representations of natural effects, and, on the other hand, how those who lacking this knowledge are only successful in producing misrepresentations and distortions of nature, we shall on a subsequent occasion give a series of notes upon those pictures which fall within the reach of our remarks. In some pictures the ignorance of one part of nature has been as great as if a portrait painter had painted a face in which the mouth was represented between the eyes and 